\title{
Lipid profile of lamb meat from different genotypes submitted to diets with different energy levels
}

\author{
Roberto Germano Costa ${ }^{1}$, Ana Sancha Malveira Batista ${ }^{2}$, Paulo Sérgio de Azevedo ${ }^{3}$, Rita de \\ Cássia Ramos do Egypto Queiroga ${ }^{4}$, Marta Suely Madruga ${ }^{5}$, José Teodorico de Araújo Filho ${ }^{6}$ \\ ${ }^{1}$ Departamento de Agropecuária, Universidade Federal da Paraíba, (DAP/CFT/UFPB), Bananeiras, Paraíba, Brasil. \\ 2 Coordenação de Zootecnia, Universidade Estadual Vale do Acaraú (DZ/UVA), Sobral, Ceará, Brasil. \\ ${ }^{3}$ Departamento de Zootecnia, Universidade Federal da Paraíba, (DZ/UFPB), Areia, Paraíba, Brasil. \\ ${ }^{4}$ Departamento de Nutrição, Universidade Federal da Paraíba (DN/UFPB), João Pessoa, Paraíba, Brasil. \\ 5 Departamento de Tecnologia e Química de Alimentos, Universidade Federal da Paraíba (DTQA/CT/UFPB), João Pessoa, Paraíba, Brasil. \\ ${ }^{6}$ Centro de Ciências Agrárias, Universidade Federal de Alagoas,(CECA/UFAL), Maceió, Alagoas, Brasil.
}

ABSTRACT - To assess the influence of genotype and diets with different energy levels on the lipid profile of sheep meat, 54 lambs were used (18 animals from each genotype: Morada Nova, Santa Inez and 1/2Dorper + 1/2Santa Inez crossbred), distributed in a completely randomized experimental design in a $3 \times 2$ factorial arragement (three genotypes and two diets) The animals were submitted to two diets, 2.5 Mcal ME/kg DM and 3.0 Mcal ME/kg DM, receiving feed and water to reach the desired average live weight of $30 \mathrm{~kg}$, when they were slaughtered. Total lipids, cholesterol, phospholipids and fatty acids profile of the Longissimus muscle were assessed. Diet and genotype did not influence the total lipids, cholesterol and phospholipids contents. The diet with the highest energy value presented higher values for the concentration of C12:0, C14:0, C18:0, C19:0, C22:0 acids and monounsaturated fatty acids (MUFA) in relation to that with the lowest energy value. However, for the concentrations of C15:0 acid and polyunsaturated fatty acids (PUFA), the highest values were recorded for diet with the lowest energy value. Genotype and diet influenced significantly the MUFA concentration, in which $1 / 2$ Dorper $+1 / 2$ Santa Inez crossbred genotype and diet with 2.5 Mcal ME/kg DM showed the highest values. Genotype influenced the saturated fatty acids (SFA) concentration, with 1/2Dorper + 1/2Santa Inez crossbred obtaining the lowest mean, behavior similar to that observed for PUFA concentrations. Desirable fatty acids (DFA), atherogenicity index as well as PUFA:SFA, MUFA:SFA, (C18:0 + C18:1):C16:0 ratios were influenced by diet and genotype. 1/2Dorper + 1/2Santa Inez crossbred and diet with 2.5 Mcal ME/kg DM obtained the best results.

Key Words: cholesterol, Dorper, fatty acids, Morada Nova, phospholipids, Santa Inez

\section{Perfil lipídico da carne ovina de diferentes genótipos mantidos com dietas com diferentes níveis energéticos}

RESUMO - Para avaliar a influência do genótipo e de dietas com diferentes níveis energéticos sobre o perfil lipídico da carne ovina, foram utilizados 54 cordeiros (18 animais de cada genótipo: Morada Nova, Santa Inês e mestiço 1/2Dorper + 1/2Santa Inês) distribuídos em delineamento experimental inteiramente ao acaso, em esquema fatorial $3 \times 2$ (três genótipos e duas dietas). Os animais foram mantidos com duas dietas (com 2,5 Mcal EM/kg MS ou 3,0 Mcal EM/kg MS) recebendo alimentação e água à vontade até atingirem o peso vivo médio de $30 \mathrm{~kg}$, quando foram abatidos. Determinaram-se os lipídios totais, o colesterol, os fosfolipídios e o perfil de ácidos graxos do músculo Longissimus. A dieta e os genótipos não influenciaram os teores de lipídios totais, colesterol e fosfolipídios. A dieta com maior valor energético apresentou valores mais elevados para concentração dos ácidos C12:0, C14:0, C18:0, C19:0, C22:0 e dos ácidos graxos monoinsaturados (AGM) em comparação àquela com menor valor energético. As maiores concentrações do ácido C15:0 e de ácidos graxos poliinsaturados (AGP) foram obtidas com a dieta de menor valor energético. O genótipo e a dieta influenciaram a concentração dos AGM, que foi maior nos mestiços $1 / 2$ Dorper $+1 / 2$ Santa Inês mantidos com a dieta com 2,5 Mcal EM/kg MS. O genótipo influenciou a concentração dos ácidos graxos saturados (AGS), uma vez que os mestiços $1 / 2$ Dorper $+1 \frac{1}{2}$ Santa Inês apresentaram a menor média, comportamento semelhante ao observado para as concentrações dos AGP. Os ácidos graxos desejáveis (AGD), o índice de aterogenicidade e as relações AGP:AGS, AGM:AGS, (C18:0 + C18:1):C16:0 foram influenciados pelo genótipo e pela dieta. O genótipo $1 / 2$ Dorper $+1 / 2$ Santa Inês e a dieta com 2,5 Mcal EM/kg MS possibilitaram os melhores resultados.

Palavras-chave: ácidos graxos, colesterol, Dorper, fosfolipídios, Morada Nova, Santa Inês 


\section{Introduction}

Sheep meat is a source of protein with high biological value, deserving special attention by the different segments of the production chain, considering the increase in the consumers' demand level and the expansion of markets.

Morada Nova and Santa Inez native breeds have great importance for the Brazilian Northeastern economy and meat fitness with rusticity characteristics, being well adapted to the inhospitable conditions of semi-arid regions. The genetic group Dorper, from South Africa, has stood out due to its importance for the crossing with native breeds, such as Santa Inez, resulting in the production of lambs with rapid growth and high-quality carcass (Garcia et al., 2000).

Additionally, studies have been directed to assess the influence of diet on the chemical quality of sheep meat. The results obtained in relation to the effect of diet on the fat content of sheep meat have been contradictory, an example is the research of Madruga et al. (2005), who reported the effect of the use of diets with different compositions on the fat content ( 2.74 and $8.38 \mathrm{~g} / 100 \mathrm{~g}$ ) of sheep meat; however, Bonagúrio et al. (2004) verified opposite effect working with Texel lambs fed with several diets ( 2.4 and $4.5 \mathrm{~g} / 100 \mathrm{~g}$ ).

Wood et al. (2008) on his extensive review on fat and meat quality recommended to consumers a reduction in the fat ingestion, especially those rich in cholesterol and saturated fatty acids (SFA), and an increasing intake of monounsaturated (MUFA) and polyunsaturated fatty acids (PUFA), with the aim of reducing the risk of obesity, cancer and cardiovascular diseases.

The composition of fatty acid (FA) present in muscle and fat tissue reflects the breeding conditions of animals and have a remarkable effect on the meat quality, being worth stressing that lambs raised on pasture produce meat with quality more favorable to the consumers' health than those raised in stalls, because their FA profile show higher concentrations of conjugated linoleic acid (C18:2 - CLA), C18:3 n-3 (linolenic acid), long chain PUFA n-3 and a higher C18:2 n-6:C18:3 n-3 ratio (Aurousseau et al., 2007).

Considering the importance of native breeds and the difficult conditions that the sheep breeding activity finds to develop in semi-arid regions, the present research was conducted with the objective of evaluating the effect of diets with different energy concentrations used in the termination of native and crossbred sheep on the lipid profile of the meat from these animals.

\section{Material and Methods}

This experiment was conducted at the Pendência Experimental Station, which belongs to the State of Paraiba Agriculture and Cattle Raising Research Company (EMEPA), located at the municipality of Soledade - Paraiba, Brazil.

Fifty-four whole male animals were used, 18 from each genotype: Morada Nova, Santa Inez and $1 / 2$ Dorper $+1 / 2$ Santa Inez crossbred, in a feedlot system. Morada Nova animals had approximately 150 days of age and an average weight of $14.98 \mathrm{~kg}$; while Santa Inez and 1/2Dorper $+1 / 2$ Santa Inez genotypes were 100 days olds and presented an average weight of 17.63 and $17.80 \mathrm{~kg}$, respectively. At the beginning of the experiment, all 54 lambs were divided into two groups, each group containing nine animals from each genotype, and submitted to two diets containing different energy levels: 2.5 Mcal ME/kg DM and 3.0 Mcal ME/kg DM, until they reached the average live weight of $30 \mathrm{~kg}$.

The period of adaptation to stalls and diets was 14 days, during which the animals were vaccinated against clostridiosis and received oral moxidectin-based parasiticide at $1 \%$. For the eimeriosis control, sulfaquinoxalin sodium $25 \mathrm{~g}$ was used during four days.

Ingredients used in diets were: Tifton hay (Cynodum $s p$ ), soybean meal, corn, urea, mineral salt and enriched palm meal, this latter obtained through fermentation process in the presence of mineral mix (Table 1). The diets in the form of full mixture were made for a daily gain of $250 \mathrm{~g} /$ day (NRC, 1985). The feed and water supply were ad libitum. Diet samples were collected for chemical analysis regarding dry matter (DM), crude protein (CP) and ether extract (EE) as methodologies described by AOAC (2000), and neutral detergent fiber (NDF) and acid detergent fiber (ADF) as described by Goering \& Van Soest (1970).

The animals were slaughtered when the desired final weight was reached, being submitted to a previous period of solid fasting and hydric diet for a period of 16 hours. The slaughter method used was stunning with brain concussion, followed by bleeding, skinning and gutting. The carcasses were washed, weighed and chilled in a cold room at $4{ }^{\circ} \mathrm{C}$ for 24 hours. After that, samples from the Longissimus muscle (LM) were desiccated, vacuum packed, frozen and stored at $-20^{\circ} \mathrm{C}$ for later laboratory tests for a period no longer than 90 days until the beginning of the analyses.

For the total lipids, cholesterol, phospholipids and FA profile analyses, the subcutaneous and epimisium fat tissue was removed from LM samples. The samples were thawed overnight and completely minced and homogenized before 
Table 1 - Composition of experimental diets

\begin{tabular}{|c|c|c|}
\hline \multirow[t]{2}{*}{ Ingredient (\%) } & \multicolumn{2}{|c|}{ Diet (Mcal ME/kg DM) } \\
\hline & 2.5 & 3.0 \\
\hline Corn meal & 25 & 50.5 \\
\hline Soybean meal & 10 & 15 \\
\hline Enriched palm meal ${ }^{1}$ & 33 & 14 \\
\hline Tifton hay & 30.5 & 19 \\
\hline Urea & 1 & 1 \\
\hline Mineral salt ${ }^{2}$ & 0.5 & 0.5 \\
\hline \multicolumn{3}{|l|}{ Chemical composition (\%) } \\
\hline Dry matter & 90.9 & 90.4 \\
\hline Mineral matter & 14.5 & 13.2 \\
\hline Crude protein & 18.6 & 19.6 \\
\hline Neutral detergent fiber & 41.7 & 33.6 \\
\hline Acid detergent fiber & 19.6 & 13.7 \\
\hline Total digestible nutrients & 69.4 & 81.7 \\
\hline Ether extract & 2.3 & 2.9 \\
\hline
\end{tabular}

starting the tests, and three replicated per sample were used (Madruga et al., 2001).

The total lipids were extracted in chloroform: methanol solution (2:1 vol/vol), according to procedures of method proposed by Folch et al. (1957) and extracts used in the fatty acids, cholesterol and phospholipids analyses. The phospholipids content was determined in accordance with methodology described by Pikul et al. (1985) and adapted by Madruga et al. (2001), with colorimetric reading in spectrometer (METERTEC, model SP-818, Brazil), at wavelength of $660 \mathrm{~nm}$ of absorbance (Rangana, 1991). The cholesterol dosage was carried out in accordance with methodology described by Bragagnolo \& RodriguezAmaya (1992), through spectrometer (MICRONAL, model B395, Sao Paulo, Brazil), in absorbance with wavelength of $490 \mathrm{~nm}$. The analytical curve was performed with standard cholesterol P.A. (VETEC, Rio de Janeiro, Brazil), based on a standard solution prepared with $10 \mathrm{mg}$ of cholesterol in $100 \mathrm{~mL}$ of hexane, with concentrations ranging from 0.1 to $0.6 \mathrm{mg} / \mathrm{mL}$.

In determining the FA profile of sheep meat, the lipids, after extraction, were esterified and methylated according to method described by Hartmam \& Lago (1973). The methyl esters of fatty acids were separated and quantified in a gas chromatograph (GC-QP5050A, Shimadzu, Brazil) equipped with polar-type cast-silicon capillary column Carbowax 20M (SUPELCO, USA) wrapped in polyethylene, with the following dimensions: $60 \mathrm{~m}$ x 0,53 mm i.d. x $1 \mu \mathrm{m}$ of film thickness, using $\mathrm{H}_{2}$ as carrier gas at a flow rate of $40 \mathrm{~cm} / \mathrm{sec}$. Samples of methyl esters $(1.0 \mu \mathrm{L})$ were introduced in a split/ splitless type injector at a temperature of $230^{\circ} \mathrm{C}$. The initial and final temperatures were, respectively, 120 and $210^{\circ} \mathrm{C}$, with intermediate ramp of $8^{\circ} \mathrm{C} / \mathrm{min}$, and the detector temperature was maintained at $250^{\circ} \mathrm{C}$. In order to be quantified, the areas under the peaks were recorded in Peaksimple-type software (ARI Instruments, USA). FA were identified by comparing the retention times of methyl esters from samples with authentic patterns of esters from fatty acids (Merck, USA).

The animals were distributed in a completely randomized experimental design, in a $3 \times 2$ factorial scheme, with nine replicates per treatment. Three genotypes (Morada Nova, Santa Inez and $1 / 2$ Dorper $+1 / 2$ Santa Inez) and two diets (2.5 Mcal ME/kg DM and 3.0 Mcal ME/kg DM) were tested. The mathematical model included genotype, diet, and the genotype $\times$ diet interaction as sources of variation. Data were submitted to analysis of variance and, whenever necessary, the means were compared through the Tukey test at $5 \%$ probability.

\section{Results and Discussion}

The lipid values obtained were quite homogeneous, ranging from 2.15 to 2.36\%, with no variation ( $\mathrm{P}>0.05$ ) between genotypes and diets (Table 2).

The effect of diet on the lipids profile in sheep meat was observed by Madruga et al. (2005), who reported this interference, while Zapata et al. (2001) and Almeida Jr. et al. (2004) found no effect of diet on the lipids profile of sheep meat. Despite this controversy, the authors found values close to those observed in this study.

A study conducted by Zapata et al. (2003) showed that the fat deposition in the carcass of sheep occurs mainly in the subcutaneous layer, and the proportion of fat is smaller in entire males, as the animals used in this study, than in castrated males or females.

According to Garcia et al. (2000), there are evidences that the Santa Inez breed, when terminated under feedlot presents potential for the production of meat with lower amounts of fat, which may explain the concentrations of total lipids found in this experiment.

Factors genotype and diet did not interfere in the cholesterol levels of the sheep meat, showing variation of the averages obtained from 65.58 to $67.88 \mathrm{mg} / 100 \mathrm{~g}$ (Table 2). Perez et al. (2002) assessed the meat from Santa Inez and Bergamácia lambs slaughtered at different weights $(15,25$, 35 and $45 \mathrm{~kg}$ ) and observed that the cholesterol level decreased with the increased weight at slaughter, and reported value of $67.57 \mathrm{mg} / 100 \mathrm{~g}$ for animals slaughtered at 
Table 2 - Fat cholesterol percentage and phospholipids contents (mg/100g) of meat from Morada Nova, Santa Inez and 1/2 Dorper $+1 / 2$ Santa Inez $(1 / 2 \mathrm{D}+1 / 2 \mathrm{SI})$ genotypes submitted to diets with different energy concentrations

\begin{tabular}{lccc}
\hline Source & Fat $(\mathrm{g} / 100 \mathrm{~g})$ & Cholesterol $(\mathrm{mg} / 100 \mathrm{~g})$ & Phospholipids $(\mathrm{mg} / 100 \mathrm{~g})$ \\
\hline Genotype & & & \\
Morada Nova & $2.25 \pm 0.48$ & $66.87 \pm 2.70$ & $6.94 \pm 2.20$ \\
Santa Inez & $2.22 \pm 0.42$ & $65.88 \pm 3.10$ & $9.12 \pm 4.10$ \\
$1 / 2 \mathrm{D}+1 / 2 \mathrm{SI}$ & $2.15 \pm 0.78$ & $67.88 \pm 8.20$ & $7.61 \pm 4.50$ \\
Diet & & & \\
2.5 Mcal ME/kg MS & $2.05 \pm 0.54$ & $65.58 \pm 2.92$ & $8.97 \pm 4.41$ \\
3.0 Mcal ME/kg MS & $2.36 \pm 0.57$ & $67.17 \pm 6.83$ & $6.80 \pm 2.40$ \\
CV & 26.19 & 8.21 & 46.94 \\
\hline
\end{tabular}

No significant difference $(\mathrm{P}>0.05)$ was observed for any of the factors evaluated. $\mathrm{CV}=$ coefficient of variation.

$35 \mathrm{~kg}$, which is in agreement with values obtained in this study, in which animals were slaughtered only when reaching $30 \mathrm{~kg}$.

However, there is a disagreement regarding the results presented in literature in relation to the effect of genotype and diet on the cholesterol concentrations of sheep meat. Zapata et al. (2001) observed no effect of genotype and diet on the cholesterol levels in the meat from the crossing between Brazilian breeds Somali, Criollo and Santa Inez fed with bermuda grass, leucaena hay and one group receiving, besides these, a concentrate with $20 \%$ of crude protein. On the other hand, Madruga et al. (2005) analyzed the quality of meat from Santa Inez lambs terminated with different types of feed (grass, pineapple stubbles, forage palm and corn silage) and concluded that the diet influenced this characteristic, indicating that the diet offered to the animal can improve the quality of its meat. This divergence between data is possibly due to the type of diet used.

Observing values found for phospholipids (Table 2), uniformity between genotypes and diets is verified $(\mathrm{P}>0.05)$ with averages ranging from 6.80 to $9.12 \mathrm{mg} / 100 \mathrm{~g}$ of meat.

Madruga et al. (2005) found phospholipids values ranging from 15.88 to $21.67 \mathrm{mg} / 100 \mathrm{~g}$, higher than those found in this research, the difference between values found is possibly due to diet employed. Phospholipids are structural organic compounds that have high PUFA concentrations in their composition, particularly those with three or more double bonds, such as linolenic acid (C18:3) (Fisher et al., 2000).

The FA profile in meat from ruminants was characterized by the presence of short-chain FA and small amounts of PUFA (Table 3).

The FA values observed in this evaluation show the influence $(\mathrm{P}<0.05)$ of genotypes and diets studied. Thirteen FA were identified, which represent the sum of fatty acids present in phospholipids and in the lipid fraction, composed of triglycerides and small quantities of free fatty acids.
Among the fatty acids identified, eight were SFA: capric acid (C10:0), lauric acid (C12:0), myristic acid (C14:0), pentadecanoic acid (C15:0), palmitic acid (C16:0), stearic acid (C18:0), arachidic acid (C20:0) and behenic acid (C22:0); three were MUFA: myristoleic acid (C14:1), palmitoleic acid (C16:1) and oleic acid (C18:1), and, two were PUFA, linoleic acid (C18:2) and linolenic acid (C18:3).

Among the chromatograms analyzed, FA presenting the largest area percentage was C18:1, followed by C16:0, C18:0, and C18:2. These results are similar to those found by Madruga et al. (2005), who studied the quality of meat from Santa Inez lambs terminated with different diets and found the largest area (\%) for C18:1, followed by C16:0, C18:0, C18:2, C16:1 and C14:0.

C18:1 was predominant in all treatments, and this high concentration was also reported by other authors (Banskalieva et al., 2000; Sañudo et al., 2000; Madruga et al., 2005; Madruga et al., 2006).

Morada Nova lambs achieved the highest average for C14:1, C18:3 and SFA, and this latter value was similar to that observed for Santa Inez lambs. Still in relation to Santa Inez native breed, this genotype showed higher values for C10:0, C14:0, C18:0, C16:1 and PUFA. The meat from $1 / 2$ Dorper $+1 / 2$ Santa Inez crossbred obtained the highest average for MUFA and C18:1.

According to Rhee et al. (2000), Perez et al. (2002) and Kesava Rao et al. (2003), the plasma cholesterol concentration is influenced by the fatty acids composition in diet, in which C16:0 increases, C18:1 decreases, and C18:0 does not exercise any influence on the blood cholesterol levels. It was observed that factor diet influenced the C18:1 concentration. This relationship may explain the homogeneity of the cholesterol dosage found in the meat from the different genotypes evaluated (Table 2).

According to Grundy (1994), C18:0 is considered hypolipidemic, since it plays a role in the cholesterol reduction, which results from the rapid conversion of C18:0 
Table 3 - Fatty acids composition (\%) in the lipid fraction of meat from Morada Nova, Santa Inez and 1/2Dorper $+1 / 2$ Santa Inez $(1 / 2 \mathrm{D}+1 / 2 \mathrm{SI})$ genotypes submitted to diets with different energy concentrations

\begin{tabular}{|c|c|c|c|c|c|c|}
\hline \multirow[t]{2}{*}{ Fatty acid } & \multicolumn{3}{|c|}{ Genotype } & \multicolumn{2}{|c|}{ Diet (Mcal ME/kg MS) } & \multirow[t]{2}{*}{$\mathrm{CV}$} \\
\hline & Morada Nova & Santa Inez & $1 / 2 \mathrm{D}+1 / 2 \mathrm{SI}$ & 2.5 & 3.0 & \\
\hline Saturated Fatty Acids (SFA) & $57.44 \mathrm{a}$ & $56.82 \mathrm{a}$ & $55.86 b$ & 56.09 & 56.98 & 0.83 \\
\hline Lauric acid (C12:0) & 0.45 & 0.36 & 0.47 & $0.32 \mathrm{~B}$ & $0.48 \mathrm{~A}$ & 4.56 \\
\hline Miristic acid (C14:0) & $1.08 \mathrm{c}$ & $1.16 \mathrm{a}$ & $1.14 \mathrm{~b}$ & $1.00 \mathrm{~B}$ & $1.19 \mathrm{~A}$ & 2.63 \\
\hline Pentadecanoic acid (C15:0) & $0.09 a$ & $0.09 a$ & $0.08 \mathrm{~b}$ & $0.09 \mathrm{~A}$ & $0.08 \mathrm{~B}$ & 2.68 \\
\hline Arachidic acid (C20:0) & $6.25 a$ & $6.34 \mathrm{a}$ & $5.42 \mathrm{~b}$ & 6.16 & 5.95 & 7.26 \\
\hline Behenic acid (C22:0) & 0.07 & 0.06 & 0.05 & $0.05 \mathrm{~B}$ & $0.07 \mathrm{~A}$ & 19.76 \\
\hline Monounsaturated Fatty Acids (MUFA) & $31.20 \mathrm{c}$ & $31.44 b$ & $32.90 \mathrm{a}$ & $32.07 \mathrm{~A}$ & $31.49 \mathrm{~B}$ & 0.26 \\
\hline Myristoleic acid (C14:1) & $0.05 a$ & $0.04 \mathrm{~b}$ & $0.03 c$ & $0.04 \mathrm{~B}$ & $0.04 \mathrm{~A}$ & 4.29 \\
\hline Palmitoleic acid (C16:1) & $2.04 \mathrm{c}$ & $2.27 \mathrm{a}$ & $2.21 b$ & $1.99 \mathrm{~B}$ & $2.33 \mathrm{~A}$ & 1.78 \\
\hline Oleic acid (C18:1) & $29.12 b$ & $29.13 b$ & $30.66 a$ & $30.04 \mathrm{~A}$ & $29.13 \mathrm{~B}$ & 0.29 \\
\hline
\end{tabular}

Averages followed by same letter, on the same row, small letter for genotype and capital letter for diet, are similar (P $>0.05$ ).

$\mathrm{CV}=$ coefficient of variation

into C18:1, only requiring desaturation in the n-9 portion, potential beneficial agent in reducing the cholesterol levels.

MUFA suffered influence from genotype and diet, with $1 / 2$ Dorper $+1 / 2$ Santa Inez crossbred presenting the lowest average for C14:1, which is in agreement with results found by Sañudo et al. (2000), who assessed the FA composition in the meat from British and Spanish breed lambs.

With regard to the diets used, the one with the highest energy concentration provided higher averages for most acids $(\mathrm{P}<0.05)$, except for C15:0, C18:1, C18:2 and C18:3.

The results presented in this work with respect to the total MUFA, SFA and PUFA percentage, differed from values reported by Rizzi et al. (2002) and Tshabalala et al. (2005), who found MUFA percentages higher than those of this evaluation and lower for other summations.

The genotype factor influenced the summation of MUFA, SFA and PUFA, while diet showed difference $(\mathrm{P}<0.05)$ only for MUFA and PUFA. Madruga et al. (2005) evaluated the quality of meat from Santa Inez lambs terminated with different diets and found values ranging from 50.51 to $47.18 \%$ for SFA; from 51.81 to $44.50 \%$ for MUFA and from 5.01 to $2.25 \%$ for PUFA. The values of the first summations are lower than those found in this research, while for MUFA and PUFA, the behavior was the opposite, stressing that this increase is due to the high linoleic acid percentage found in treatments, indicating an increase in the PUFA:SFA ratio, important to the consumers' health (Wood et al., 2003).

In this work, it was found that the meat from $1 / 2$ Dorper $+1 \frac{1}{2}$ Santa Inez crossbred lambs stands out in the nutritional aspect due to its higher C18:1 fatty acid and MUFA contents, while Santa Inez genotype showed higher SFA values, which is a less desirable nutritional condition. Diets had influenced the PUFA profile for the genotype studied, with the lowest energy concentration presenting the best averages.

Relations or proportions have been suggested as a way of assessing the risk factor of foods in relation to the increase in the blood cholesterol levels; since it is known that SFA increases the plasma cholesterol levels, while PUFA lower them. According to Banskalieva et al. (2000), it is possible to express the concentration of desirable fatty acids (DFA) through the sum of unsaturated fatty acid with stearic acid. The stearic acid (C18:0), although saturated, is neutral, and has fewer implications in the lipid profile, since it can be converted into oleic acid (C18:1) in the body; however, monounsaturated acids, oleic acid, polyunsaturated acids, linolenic acid and $\alpha$-linolenic acid reduce the LDLcholesterol levels, and thus the risk of obesity, cancer and cardiovascular diseases (Perez et al., 2002).

The influence of genotype and diets was observed in all presented relations (Table 4). $1 / 2$ Dorper $+1 / 2$ Santa Inez crossbred lambs obtained the desirable average for the atherogenicity index, and high MUFA:SFA and (C18:0 + C18:1):C16:0 ratios, while Santa Inez lambs obtained the highest average for the PUFA:SFA ratio. For DFA and n6:n3 ratio, these two genotypes were similar (Table 4).

The biological effect of essential FA depends on the PUFA:MUFA and PUFA:SFA ratios. The high C18:1 content and the consequent increase in the PUFA:SFA ratio are 
Table 4 - Averages of relations between saturated, monounsaturated and polyunsaturated fatty acids in the meat from Morada nova, Santa Inez and $1 / 2$ Dorper $+1 / 2$ Santa Inez $(1 / 2 \mathrm{D}+1 / 2 \mathrm{SI})$ genotypes submitted to diets with different energy concentrations

\begin{tabular}{|c|c|c|c|c|c|c|}
\hline \multirow[t]{2}{*}{ Fatty acid } & \multicolumn{3}{|c|}{ Genotype } & \multicolumn{2}{|c|}{ Diet (Mcal ME/kg MS) } & \multirow[t]{2}{*}{$\mathrm{CV}$} \\
\hline & Morada Nova & Santa Inez & $1 / 2 \mathrm{D}+1 / 2 \mathrm{SI}$ & 2.5 & 3.0 & \\
\hline PUFA: SFA1 & $0.20 \mathrm{~b}$ & $0.21^{\mathrm{a}}$ & $0.20 \mathrm{~b}$ & $0.21 \mathrm{~A}$ & $0.20 \mathrm{~B}$ & 1.81 \\
\hline DFA3 & $66.53 b$ & $67.41^{\mathrm{a}}$ & $68.21^{\mathrm{a}}$ & $67.60 \mathrm{~A}$ & $67.28 \mathrm{~B}$ & 0.33 \\
\hline n6: n3 & $15.11 b$ & $16.65 a b$ & $17.89^{\mathrm{a}}$ & $16.74 \mathrm{~B}$ & $18.14 \mathrm{~A}$ & 6.46 \\
\hline Atherogenicity index 4 & $0.70^{\mathrm{a}}$ & $0.68 b$ & $0.67 c$ & $0.66 \mathrm{~B}$ & $0.69 \mathrm{~A}$ & 0.86 \\
\hline
\end{tabular}

${ }^{1}$ PUFA:SFA: ratio between polyunsaturated and saturated fatty acids; ${ }^{2}$ MUFA:SFA: ratio between saturated and monounsaturated fatty acids; ${ }^{3}$ DFA: desirable fatty acids = MUFA + PUFA + C18:0, ${ }^{4}[(\mathrm{C} 12: 0+(4 * \mathrm{C} 14: 0)+\mathrm{C} 16: 0)] /$ sum of unsaturated fatty acids.

Averages followed the same letter in the same row, small letter for genotypes and capital letter for diets, do not differ $(\mathrm{P}<0.05)$.

$\mathrm{CV}=$ coefficient of variation.

important to reduce the risk of cardiovascular diseases. Thus, this index is used to calculate the risk factor of foods, and it is strongly recommended that this ratio should be at least 0.4 (Wood et al., 2003) or 0.12 as the upper limit (Hoffman et al., 2003). Lower values were described by Banskalieva et al. (2000) in sheep meat, which ranged from 0.07 to 0.26 . It is noteworthy, however, that this index is correlated with the $n 6: n 3$ ratio, since the increase in the linolenic acid content, which is polyunsaturated, will reduce this ratio.

Lipids present in the diet of ruminants affect the FA composition of their meat, because the biohydrogenation is less effective, raising the UFA levels in the fat of these animals (Santos-Silva et al., 2002). If the UFA levels are high in the rumen, it will also raise the oleic acid concentration due to the inhibition of the last biohydrogenation stage (Palmquist \& Mattos, 2006).

Animals that feed on forage containing high C18:3 levels provide meat with low $\mathrm{n} 6: \mathrm{n} 3$ ratio, such as ruminants. Therefore, values lower than 4 for this ratio are recommended because it is associated with the onset of arteriosclerosis and cardiovascular problems(Wood etal., 2003; Insausti etal., 2004).

The values found for these relations in this research are consistent with those reported by Madruga et al. (2005), who worked with Santa Inez lambs terminated with different diets and observed for animals fed with forage palm, values for PUFA: SFA, MUFA: SFA, DFA and(C18:0+C18:1):C16:0 ratios of $0.10,0.89,70.27$ and 2.76 , respectively.

Banskalieva et al. (2000), argued that the (C18:0 + C18:1):C16:0 ratio describes possible beneficial effects of different lipids found in red meat, with values from 2.1 to $2.8 \%$ for sheep meat. Considering the variation presented by these authors, it was observed that the ratio found in this work seemed to be within the recommended range.

The DFA values in this work ranged from 69.43 to $70.74 \%$ for genotypes evaluated (Table 3). Madruga et al.
(2005) found DFA values ranging from 70.27 to $72.48 \%$ for meat from Santa Inez lambs, while Banskalieva et al. (2000) analyzed several sheep meats and found values from 64 to $72 \%$, both these works presented values lower than those reported in this research.

\section{Conclusions}

Genotype and diet influenced the fatty acids profile of meat from lambs, with $1 / 2$ Dorper $+1 / 2$ Santa Inez crossbred lambs obtaining the most desirable values for the ratios evaluated, indicating a better nutritional profile. Diet with 2.5 Mcal ME/ kg DM interfered similarly and could be used for lambs under feedlot system.

\section{Literature Cited}

ALMEIDA JR., G.A.; COSTA, C.; MONTEIRO, A.L.G. et al. Desempenho, características de carcaça e resultado econômico de cordeiros criados em creep feeding com silagem de grãos úmidos de milho. Revista Brasileira de Zootecnia, v.33, n.4, p.1039-1047, 2004.

ASSOCIATION OF OFFICIAL ANALITICAL CHEMISTS - AOAC. Official methods of analysis. 19.ed. Washington, D.C.: 2000. 1219p.

AUROUSSEAU, B.; BAUCHART, D.; FAURE, X. et al. Indoor fattening of lambs raised on pasture: (1) Influence of stall finishing duration on lipid classes and fat acids in the Longissimus thoracis muscle. Meat Science, v.76, p.241-252, 2007.

BANSKALIEVA, V.; SAHLU, T.; GOETSCH, A.L. Fatty acid composition of goat muscles and fat depots: a review. Small Ruminant Research, v.37, n.3, p.255-268, 2000.

BONAGURIO, S.; PEREZ, J.R.O.; GARCIA, I.F.F. et al. Composição centesimal da carne de cordeiros Santa Inês puros e de seus mestiços com Texel abatidos com diferentes pesos. Revista Brasileira de Zootecnia, v.33, n.6, p.2387-2393, 2004 (supl.3).

BRAGAGNOLO, N.; RODRIGUEZ-AMAYA, D.B. Teores de colesterol em carne suína e bovina e efeito de cozimento. Ciência e Tecnologia de Alimentos, v.15, n.1, p.11-17, 1992.

FISHER, A.V.; ENSER, M.; RICHARDSON, R.I. et al. Fatty acid composition and eating quality of lamb types derived from four diverse breed x production systems. Meat Science, v.55, p.141-147, 2000. 
FOLCH, J.; LESS, M.; STANLEY, S. A simple method for the isolation and purification of total lipids from animal tissues. Journal Biological Chemistry, v.226, n.1, p.497-509, 1957.

GARCIA, I.F.F.; PEREZ, J.R.O.; OLIVEIRA, M.V. Características de carcaça de cordeiros texel $\mathrm{x}$ bergamácia, texel $\mathrm{x}$ santa inês e santa inês puros, terminados em confinamento, com casca de café como parte da dieta. Revista Brasileira de Zootecnia, v.29, n.1, p.253-260, 2000.

GOERING, H.K.; Van SOEST, J. Forage fiber analysis. Washington, D.C.: 1970. 20p. (Agricultural Handbook, 379).

GRUNDY, S.M. Influence of stearic acid in cholesterol metabolism relative to the other long chain fatty acids. American Journal Nutrition, v.60, p.986, 1984.

HARTMAM, L.; LAGO, B.C. A rapid preparation of fatty methyl esters from lipids. Laboratory Practice, v.22, p.475-477, 1973.

HOFFMAN, L.C.; MULLER, M.; CLOETE, S.W.P. et al. Comparison of six crossbreed lamb types: sensory, physical and nutritional meat quality characteristics. Meat Science, v.65, p.1265-1274, 2003.

INSAUSTI, K.; BERIAN, M.J.; ALZUETA, M.J. et al. Lipid composition of the intramuscular fat of beef from Spanish cattle breeds stored under modified atmosphere. Meat Science, v.66, p.639-646, 2004.

KESAVA RAO, V.; KOWALE, B.N.; VERMA, A.K. Effect of feeding water washed neem seed kernel cake on the quality, lipid profile and fatty acid composition of goat meat. Small Ruminat Research, v.47, n.3, p.213-219, 2003.

MADRUGA, M.S.; ARAÚJO, W.O.; SOUSA, W.H. et al. Efeito do genótipo e do sexo sobre a composição química e perfil dos ácidos graxos da carne de cordeiros. Revista Brasileira de Zootecnia, v.35, n.4, p.1838-1844, 2006 (supl.).

MADRUGA, M.S.; SOUSA, W.H.; ROSALES, M.D. et al. Qualidade da carne de cordeiros Santa Inês terminados com diferentes dietas. Revista Brasileira de Zootecnia, 34, n.1, 309-315, 2005.

MADRUGA, M.S.; SOUZA, J.G.; NARAIN, N. Castration and slaughter age effects on fat components of "Mestiço" goat meat. Small Ruminant Research, v.42, n.1, p.77-82, 2001.

NATIONAL RESEARCH COUNCIL - NRC. Nutrient requirements of domestic animals: nutrient requirements of sheep. 6.ed. Washington, D.C.: National Academy, 1985. 99p.

PALMQUIST, D.L.; MATTOS, W.R.S. Metabolismo de lipídeos. In: BERCHIELLI, T.T., PIRES, A.V.; OLIVEIRA,
S.G. (Eds.) Nutrição de ruminantes. Jaboticabal: FUNEP, 2006. p.287-310.

PEREZ, J.R.O.; BRESSAN, M.C.; BRAGAGNOLO, N. et al. Efeito do peso ao abate de cordeiros Santa Inês e Bergamácia sobre o perfil de ácidos graxos, colesterol e propriedades químicas. Ciência e Tecnologia de Alimentos, v.22, n.1, p.11-18, 2002.

PIKUL, J.; LESZCZYNSKI, D.E.; KVMMEROW, F.A. Influence of fat content and composition on malomaldehyde concentration in chicken meat and skin. Poultry Science, v.64, p.311-317, 1985.

RANGANA, S. Handbook of analysis and qaulity control for fruits and vegetable products. New Delhi: Mcgraw-Hill, 1991. $1112 \mathrm{p}$.

RHEE, K.S.; WALDRON, D.F.; ZIPRIN, Y.A. et al. Fatty acid composition of goat diets vs intramuscular fat. Meat Science, v.54, p.313-318, 2000 .

RIZZI, L.; SIMIOLI, M.; SARDI, L. et al. Carcass quality meat chemical and fatty acid composition of lambs fed diets containing extruded soy beans and sunflower seeds. Animal Feed Science and Technology, v.97, p.130-114, 2002.

SANTOS-SILVA, J.; BESSA, R.J.B.; MENDES, I.A. The effect of genotype, feeding system and slaughter weight on the quality of light lamb. II. Fatty acid composition of meat. Livestock Science, v.77, p.187-194, 2002

SAÑUDO, M.E.; ENSER, M.M.; CAMPO, G.R. et al. Fatty acid composition and sensory characteristics of lambs carcass from Britain and Spain. Meat Science, v.54, p.339-346, 2000.

TSHABALALA, P.A.; STRYDOM, P.E.; WEBB, E.C. et al. Meat quality of designated South African Indigenous goat and sheep breeds. Meat Science, v.65, p.563-570, 2005.

WOOD, J.D.; ENSER, M.; FISHER, A.V. et al. Fat deposition, fatty acid composition and meat quality: a review. Meat Science, v.78, p.343-358, 2008.

WOOD, J.D.; RICHARDSON, R.L.; NUTE, G.R. et al. Effects of fatty acids on meat quality: a review. Meat Science, v.66, p.21-32, 2003.

ZAPATA, J.F.F.; NOGUEIRA, C.M.; SEABRA, L.M.J. et al. Características da carne de pequenos ruminantes do Nordeste do Brasil. Boletim da Sociedade Brasileira de Ciência e Tecnologia de Alimentos, v.37, n.2, p.146-153, 2003.

ZAPATA, J.F.F.; NOGUEIRA, C.M.; SEABRA, L.M.J. et al. composição centesimal e lipídica da carne de ovinos do nordeste brasileiro. Ciência Rural, v.31, n.4, p.691-695, 2001. 